\title{
Effect of Heartwood and Sapwood Ratio on Adhesion Strength of Finished Wood Species
}

\author{
Turgay Ozdemir, ${ }^{1}$ Salim Hiziroglu, ${ }^{2}$ and Mutlu Kocapınar ${ }^{1}$ \\ ${ }^{1}$ Department of Forest Products Engineering, Karadeniz Technical University, 61080 Trabzon, Turkey \\ ${ }^{2}$ Natural Resource Ecology and Management, Oklahoma State University, Stillwater, OK 74078, USA \\ Correspondence should be addressed to Salim Hiziroglu; salim.hiziroglu@okstate.edu
}

Received 8 May 2015; Accepted 24 June 2015

Academic Editor: Luigi Nicolais

Copyright (c) 2015 Turgay Ozdemir et al. This is an open access article distributed under the Creative Commons Attribution License, which permits unrestricted use, distribution, and reproduction in any medium, provided the original work is properly cited.

\begin{abstract}
The objective of this study was to determine adhesion strength of samples from wood species coated with cellulose varnish as function of heartwood and sapwood ratio. Roughness of the specimens from four different species was measured employing stylus type equipment before they were coated with varnish. Pull-off testing unit was employed to determine adhesion strength of the samples. Based on the findings in this work it seems that no significant difference was determined between adhesion strength values of the samples prepared from heartwood and sapwood portions. The highest adhesion strength value of $2.62 \mathrm{~N} / \mathrm{mm}$ was found for the beech samples sanded with 80-grit sand paper. Overall rougher surfaces of the samples resulted in higher adhesion strength between finish and substrate.
\end{abstract}

\section{Introduction}

Finishing of wood material is one of the most important processes influencing overall quality of the final product. Physical characteristics in particular appearance of the finished product are affected by not only the type of finish but also the interaction between finish and the substrate. It is a well-known fact that species, wood density, and roughness of the substrate are considered major parameters to have an effective finishing process. Wood being nonhomogenous material also creates certain challenges for an ideal finished member. Sapwood and heartwood ratio within its anatomical structure would also be an important element affecting interaction between the finishing material and the substrate. In certain species having extractives and other chemicals in the heartwood would create some barrier having good adherence of finish to the surface of wood substrate. Various studies investigated adhesion strength of different wood species coated using different types of finishing materials [1-4]. In one of these past works surface roughness of beech, spruce, fir, and alder specimens were measured using stylus type equipment before they were coated with cellulosic based varnish [5]. Adhesion strength of such samples was determined and it was found that rougher specimens resulted in higher strength values than those of smoother samples [5]. In another study moisture content of different wood species was determined as an important factor influencing overall adhesion strength of the finish [4]. Zavarin found that porosity of wood can be considered as an important factor influencing adhesion strength of finished samples [3].

Penetration of the coating material into the wood is substantially influenced by its porosity, capillarity, and dimensional stability [6]. If flexibility of any kind of finish including vanishes is exceeded by fluctuation of moisture content of wood certain defects such as cracks and splits in finish would be inevitable [6-8]. Such stresses can be controlled at certain level by drying wood to a target moisture content. Additionally even insignificant differentiation in shrinkage and swelling of sapwood and heart wood would result in some finishing defects. Tension strength perpendicular to surface plane of coated wood species can be defined as adhesion strength [8]. Basic mechanism of adhesion between coating and wood substrate has also been evaluated in various past studies [2-4].

Pull-off test set-up is one of the most commonly used ones to determine adherence quality between finish and substrate. 
TABLE 1: Roughness and adhesions strength test results.

\begin{tabular}{|c|c|c|c|c|c|c|c|c|c|}
\hline \multicolumn{2}{|c|}{ Species and density } & \multicolumn{4}{|c|}{ Roughness value $\left(R_{z}\right)(\mu \mathrm{m})$} & \multicolumn{4}{|c|}{ Adhesion strength $\left(\mathrm{N} / \mathrm{mm}^{2}\right)$} \\
\hline & & Spruce & Fir & Alder & Beech & Spruce & Fir & Alder & Beech \\
\hline \multirow{3}{*}{$\begin{array}{l}\text { Heartwood } \\
\text { Spruce }\left(0.425 \mathrm{~g} / \mathrm{cm}^{3}\right) \\
\text { Fir }\left(0.49 \mathrm{~g} / \mathrm{cm}^{3}\right) \\
\text { Alder }\left(0.52 \mathrm{~g} / \mathrm{cm}^{3}\right) \\
\text { Beech }\left(0.69 \mathrm{~g} / \mathrm{cm}^{3}\right)\end{array}$} & Planing & $\begin{array}{c}45.50 \\
{ }^{*}(6.91)\end{array}$ & $\begin{array}{c}41.78 \\
(3.60)\end{array}$ & $\begin{array}{l}51.49 \\
(7.25)\end{array}$ & $\begin{array}{l}48.30 \\
(3.32)\end{array}$ & $1.95(0.21)$ & $1.92(0.26)$ & $1.98(0.19)$ & $2.12(0.26)$ \\
\hline & 80 & $\begin{array}{l}43.20 \\
(5.40)\end{array}$ & $\begin{array}{l}39.22 \\
(6.01)\end{array}$ & $\begin{array}{l}42.36 \\
(4.21)\end{array}$ & $\begin{array}{l}42.57 \\
(7.02)\end{array}$ & $2.06(0.26)$ & $2.05(0.22)$ & $2.42(0.36)$ & $2.62(0.22)$ \\
\hline & 180 & $\begin{array}{l}25.78 \\
(3.73) \\
\end{array}$ & $\begin{array}{r}29.99 \\
(4.60) \\
\end{array}$ & $\begin{array}{c}31.32 \\
(3.38) \\
\end{array}$ & $\begin{array}{c}31.05 \\
(8.24)\end{array}$ & $1.97(0.17)$ & $2.01(0.19)$ & $2.36(0.33)$ & $2.56(0.27)$ \\
\hline \multirow{3}{*}{$\begin{array}{l}\text { Sapwood } \\
\text { Spruce }\left(0.420 \mathrm{~g} / \mathrm{cm}^{3}\right) \\
\text { Fir }\left(0.48 \mathrm{~g} / \mathrm{cm}^{3}\right) \\
\text { Alder }\left(0.52 \mathrm{~g} / \mathrm{cm}^{3}\right) \\
\text { Beech }\left(0.67 \mathrm{~g} / \mathrm{cm}^{3}\right)\end{array}$} & Planing & $\begin{array}{l}42.20 \\
(3.92)\end{array}$ & $\begin{array}{l}42.54 \\
(4.39)\end{array}$ & $\begin{array}{l}53.37 \\
(4.87)\end{array}$ & $\begin{array}{l}50.82 \\
(3.82)\end{array}$ & $1.97(0.30)$ & $1.88(0.32)$ & $2.13(0.35)$ & $2.40(0.33)$ \\
\hline & 80 & $\begin{array}{l}36.98 \\
(3.98)\end{array}$ & $\begin{array}{l}37.00 \\
(7.42)\end{array}$ & $\begin{array}{c}37.66 \\
(5.62)\end{array}$ & $\begin{array}{l}35.10 \\
(6.14)\end{array}$ & $2.06(0.40)$ & $2.06(0.32)$ & $2.15(0.28)$ & $2.42(0.19)$ \\
\hline & 180 & $\begin{array}{l}27.53 \\
(8.61)\end{array}$ & $\begin{array}{c}32.10 \\
(6.68)\end{array}$ & $\begin{array}{l}33.69 \\
(3.40)\end{array}$ & $\begin{array}{l}29.85 \\
(3.38)\end{array}$ & $1.92(0.25)$ & $1.91(0.29)$ & $1.92(0.12)$ & $2.36(0.25)$ \\
\hline
\end{tabular}

${ }^{*}$ Numbers in parentheses are standard deviation values.

Adhesion strength of cellulosic varnish coated wood species as function of their surface roughness was evaluated using pull-off type equipment by Ozdemir and Hiziroglu [5]. Adhesion strength of different wood species including beech, alnus, fir, spruce, oak, and maple has also been evaluated as function of their surface roughness, moisture content, and type of coating materials in several studies $[3,4,9]$. Currently there is very limited information on adhesion strength of wood species coated with cellulose varnish as function of sapwood and heartwood ratio. Therefore, the objective of this work was to get an initial data on adhesion strength characteristics of such samples from four species, namely, beech, alder, fir, and spruce coated with cellulose varnish. Results from this work are expected to be used as quality control tool to finish these species with a better efficiency and effectively so that any furniture of cabinet members manufactured from these species can be used more efficiently during their service life.

\section{Materials and Methods}

Four species, namely, beech (Fagus orientalis Lipsky), alder (Alnus gutinod-sa subsp.Barbata Yalt.), spruce (Picea orientalis L. Link), and fir (Abies nordmanniana subsp.), were used for the experiments. A total of 300 defect-free heartwood and sapwood samples with dimensions of $400 \mathrm{~mm}$ by $100 \mathrm{~mm}$ by $200 \mathrm{~mm}$ were prepared and conditioned in a climate room having a relative humidity of $65 \%$ and a temperature of $20^{\circ} \mathrm{C}$ until they reach equilibrium moisture content of $12 \%$. Conditioned specimens were sanded with 80 -grit and 180-grit sand paper using a commercial sanding machine (feed speed: $12 \mathrm{~m} / \mathrm{min}$, sanding pressure: $0.5 \mathrm{MPa}$ ). Stylus type equipment, Mitutoyo SJ-301 profilometer, was employed to measure surface roughness of the samples. Equipment has stylus with $0.5 \mu$ radius and $90^{\circ}$ contact angle running a speed of $0.5 \mathrm{~mm} / \mathrm{s}$. A total of 40 random measurements with a span of $15 \mathrm{~mm}$ were taken from the surface of each sample in radial and tangential direction across the grain orientation. Mean peak-to-valley height $\left(R_{z}\right)$ was used as an indicator for the surface quality of the samples $[10,11]$.
In the next step both heartwood and sapwood specimens were coated with cellulosic based varnish using a pressurized spray gun at a spread rate of $120 \mathrm{~g} / \mathrm{m}^{2}$ and cured in the convection drying chamber. Erichsen Adhesion-525 MC pull-off type tester was employed for adhesion strength evaluation of the specimens. Twenty-five random measurements were taken from the surface of the samples by gluing steel head with $20 \mathrm{~mm}$ diameter using epoxy resin on the samples. A constant speed of $100 \mathrm{~mm} / \mathrm{min}$ applied the force to the surface layer by pulling the coating from the surface and adhesion strength value of the finishing was determined in $\mathrm{N} / \mathrm{mm}^{2}$ on the display of the pull-off testing unit. Five $\mathrm{mm}$ small cubes from each species were also cut for microscopic evaluation. Scanning electron microscope was used to determine penetration of the coating on cross section. Finally variance analysis (ANOVA) and Duncan tests were used to analyze the experimental results.

\section{Results and Discussion}

Average $R_{z}$ and adhesion strength values of the specimens are displayed in Table 1 .

The smoothest surface having $R_{z}$ value of $25.78 \mu \mathrm{m}$ was determined for spruce samples having heartwood portion sanded with 180-grit sand paper followed by $R_{z}$ value of $27.53 \mu \mathrm{m}$ that belongs to the samples takes from sapwood of the same species. Spruce having the lowest density of $0.42 \mathrm{~g} / \mathrm{cm}^{3}$ among the four species considered in this work resulted in the smoothest surface roughness characteristics in all cases. Both beech and alder with average density values of $0.52 \mathrm{~g} / \mathrm{cm}^{3}$ and $0.68 \mathrm{~g} / \mathrm{cm}^{3}$, respectively, had higher $R_{z}$ values than those of the softwood samples as illustrated in Figure 1. It is a well-known fact that any kind of machining or sanding a denser surface creates more pronounced indentation on the substrate. In a previous work carried out on roughness measurement of ash and birch samples sanded 80- and 180grit sand paper also found similar results determined in this work $[12,13]$. 
TABLE 2: Statistical analysis of the roughness and adhesion strength test results.

\begin{tabular}{|c|c|c|c|c|c|}
\hline Source & Sum of squares & df & Mean square & $F$ value & $\begin{array}{c}\text { Significance } \\
\text { level }\end{array}$ \\
\hline \multicolumn{6}{|c|}{ Surface roughness } \\
\hline $\begin{array}{l}\text { Effect of heartwood } \\
\text { and sapwood (A) }\end{array}$ & 196,28 & 1 & 196,28 & 6,480 & NS \\
\hline Effect of sanding (B) & 28402.39 & 2 & 14201.19 & 468.825 & $* * *$ \\
\hline Effect of species (C) & 2845.37 & 3 & 948.46 & 31.312 & $* * *$ \\
\hline $\mathrm{A} \times \mathrm{B}$ & 1222.69 & 2 & 611.34 & 20.182 & $* * *$ \\
\hline $\mathrm{A} \times \mathrm{C}$ & 192.06 & 3 & 64.02 & 2.114 & NS \\
\hline $\mathrm{B} \times \mathrm{C}$ & 1693.82 & 6 & 282.30 & 9.320 & $* * *$ \\
\hline $\mathrm{A} \times \mathrm{B} \times \mathrm{C}$ & 359.39 & 6 & 59.90 & 1.977 & NS \\
\hline Error & 17447.63 & 576 & 30.29 & & \\
\hline Total & 956260.10 & 600 & & & \\
\hline \multicolumn{6}{|c|}{ Adhesion strength } \\
\hline $\begin{array}{l}\text { Effect of heart and } \\
\text { sapwood (A) }\end{array}$ & 0.57 & 1 & 0.57 & 7.70 & NS \\
\hline Effect of sanding (B) & 2.82 & 2 & 1.41 & 18.96 & $* * *$ \\
\hline Effect of species (C) & 15.29 & 3 & 5.09 & 68.46 & $* * *$ \\
\hline $\mathrm{A} \times \mathrm{B}$ & 1.91 & 2 & 0.95 & 12.84 & $* * *$ \\
\hline $\mathrm{A} \times \mathrm{C}$ & 0.60 & 3 & 0.20 & 2.72 & * \\
\hline $\mathrm{B} \times \mathrm{C}$ & 0.56 & 6 & 0.09 & 1.26 & NS \\
\hline $\mathrm{A} \times \mathrm{B} \times \mathrm{C}$ & 1.66 & 6 & 0.27 & 3.71 & $* *$ \\
\hline Error & 33.95 & 456 & 0.07 & & \\
\hline Total & 2250.38 & 480 & & & \\
\hline
\end{tabular}

NS: nonsignificant. ${ }^{*}$ Significant at the $\alpha=0.05$ level. ${ }^{* *}$ Significant at the 0.01 level. ${ }^{* * *}$ Significant at the $\alpha=0.001$ level.

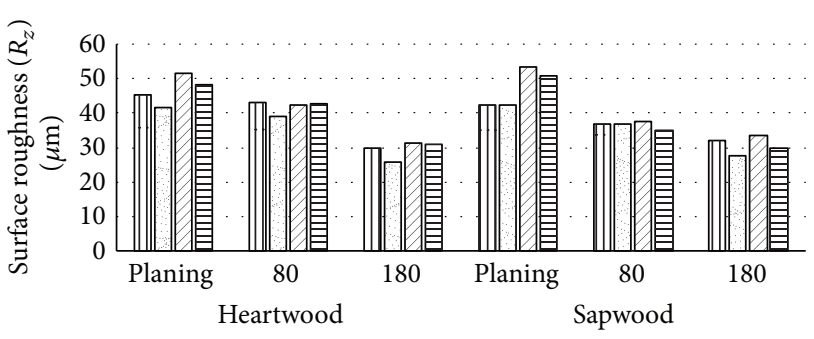

$$
\begin{array}{ll}
\square \text { Spruce } & \square \text { Alder } \\
\square \text { Fir } & \square \text { Beech }
\end{array}
$$

FIGURE 1: Mean peak-to-valley values of samples.

All four types of samples showed significant difference in their $R_{z}$ values when three types of machining and sanding processes are taken into consideration as can be seen in Table 2.

However roughness values of heartwood and sapwood portion did not show any significant difference from each other in term of their $R_{z}$ values in Table 3 . As it is expected roughness is usually considered as intent physical property of wood and wood based products. Unless the member is exposed to high relative humidity roughness may not create any substantial problem and even the surface is machined

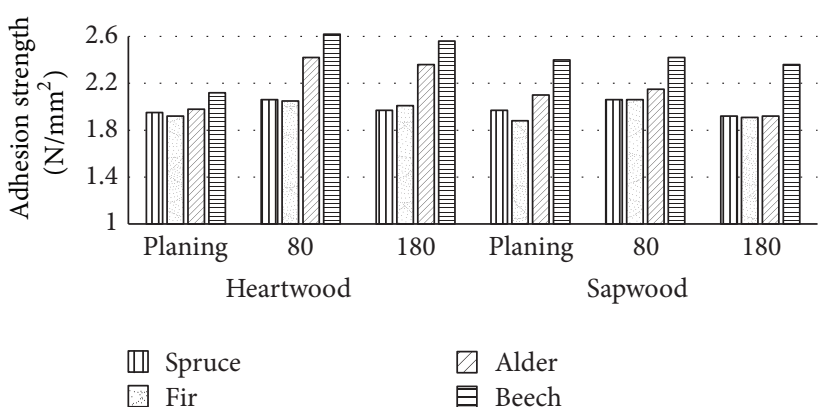

Figure 2: Adhesion strength values of the samples.

or sanded as in the case of this study. The highest and the lowest adhesion strength values of $2.62 \mathrm{~N} / \mathrm{mm}^{2}$ and $1.88 \mathrm{~N} / \mathrm{mm}^{2}$ were found for the beech heartwood sanded with 80-grit sandpaper and planed spruce samples, respectively in Figure 2. Adhesion strength of the samples takes from heartwood and sapwood portion of the trees did not show any significant difference from each other as displayed in Table 2 and Table 3. For example, in the case of spruce samples were only $1.02 \%$ of adhesion strength values of planed heartwood and sapwood.

Adhesion strength values of coated samples are shown in Figure 4 and Table 1. 
TABLE 3: Duncan test results of the samples.

\begin{tabular}{|c|c|c|c|}
\hline $\begin{array}{l}\text { Strength } \\
\text { properties }\end{array}$ & Factors & LS mean & $\begin{array}{c}\text { Homogenous } \\
\text { groups }\end{array}$ \\
\hline \multirow{12}{*}{$\begin{array}{l}\text { Surface } \\
\text { roughness }\end{array}$} & Wood species & & \\
\hline & Spruce & 38.334 & $\mathrm{~b}$ \\
\hline & Fir & 35.646 & a \\
\hline & Alder & 41.652 & c \\
\hline & Beech & 39.621 & $\mathrm{~d}$ \\
\hline & Grit size & & \\
\hline & Planing & 47.005 & c \\
\hline & 80 & 39.265 & $\mathrm{~b}$ \\
\hline & 180 & 30.170 & a \\
\hline & Wood & & \\
\hline & Heartwood & 39.386 & a \\
\hline & Sapwood & 38.242 & $\mathrm{a}$ \\
\hline \multirow{12}{*}{$\begin{array}{l}\text { Adhesion } \\
\text { strength }\end{array}$} & Wood species & & \\
\hline & Spruce & 1.99 & a \\
\hline & Fir & 1.98 & a \\
\hline & Alder & 2.16 & $\mathrm{~b}$ \\
\hline & Beech & 2.42 & c \\
\hline & Grit size & & \\
\hline & Planing & 2.05 & a \\
\hline & 80 & 2.23 & c \\
\hline & 180 & 2.13 & $\mathrm{~b}$ \\
\hline & Wood & & \\
\hline & Heartwood & 2.17 & a \\
\hline & Sapwood & 2.10 & $\mathrm{a}$ \\
\hline
\end{tabular}

* Different letter denote a statistically significant difference.

Fir samples also followed such trend and even they were sanded with 80- and 180-grit sandpaper. Influence of heartwood and sapwood ratio was slightly more pronounced in the case of hardwood species. Maximum difference in adhesion strength of the samples from heartwood and sapwood was found for alder samples sanded with 180-grit sandpaper, the reason such finding can be related to higher density and extractive contest of heartwood of alder resulting in better adherence of the varnish on the surface in contract to softwood and even beech species with lower extractive content. In a previous work adhesion strength of beech and alder samples sanded with 80- and 180-grit sandpaper without considering heartwood sapwood ratio resulted in relative similarity to those determined in this study [5]. Also both alder and beech have semiporous anatomical structure so that higher amount of varnish is absorbed resulting in better interaction between coating material and the substrate. Micrographs taken from the heartwood and sapwood samples using SEM are illustrated in Figures 3 and 4. As can be observed coating has not penetrated in the case of heartwood sample as deep as sapwood as was mentioned due to possible extractive content and another anatomical structure.

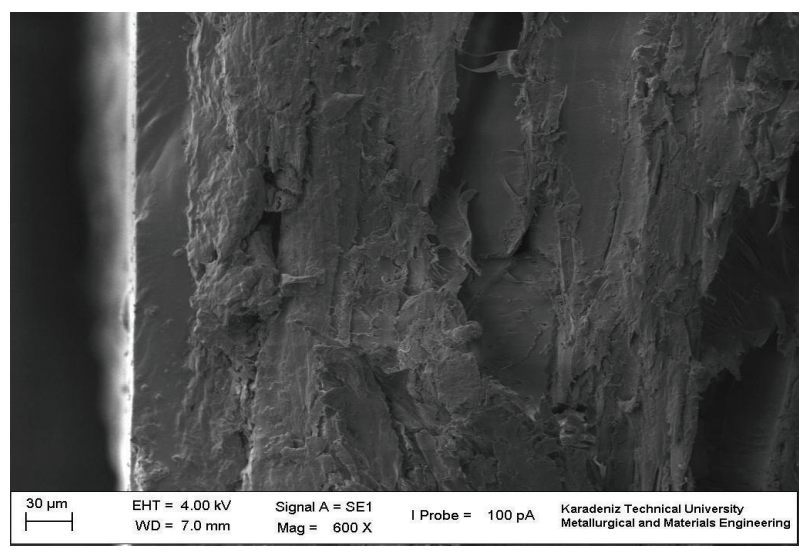

Figure 3: Cross section of heartwood beech sample.

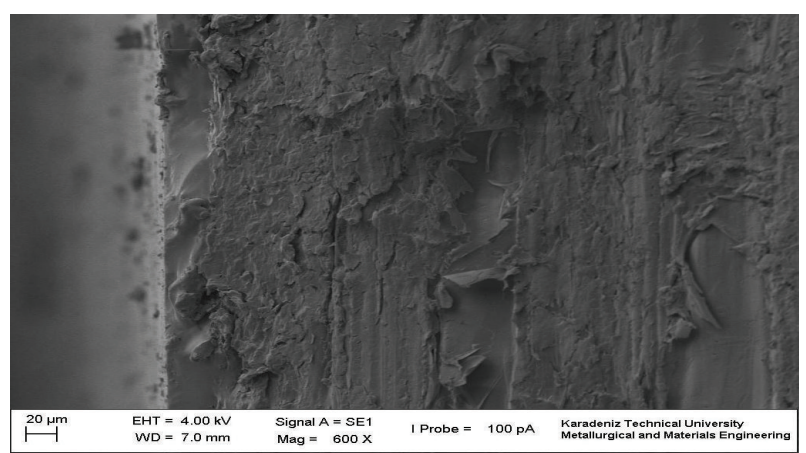

FIGURE 4: Cross section of sapwood beech sample.

\section{Conclusions}

Evaluation of adhesion strength of samples from four different species showed that no significant difference between adhesion strength values of the samples forms heartwood and sapwood portions. However, sanding with lower grit size resulted in enhanced adhesion strength characteristics between the coating and the substrate. Overall two species having denser wood showed higher adhesion strength values than those of softwood species. It appears that data from this study would have potential to determine better finishing application for the species considered in this work.

\section{Conflict of Interests}

The authors declare no conflict of interests.

\section{Acknowledgment}

This study was carried out with financial assistance by Research Program, Karadeniz Technical University, Trabzon, Turkey. 


\section{References}

[1] M. Jaic and R. Zivanovic, "The influence of the ratio of the polyurethane coating components on the quality of finished wood surface," Holz als Roh- und Werkstoff, vol. 55, pp. 319-322, 1995.

[2] M. Jaić, R. Živanović, T. Stevanović-Janežsć, and A. Dekanski, "Comparison of surface properties of beech- and oakwood as determined by ESCA method," Holz als Roh- und Werkstoff, vol. 54, no. 1, pp. 37-41, 1996.

[3] E. Zavarin, "Activation of wood surface and non-convential bonding," in The Chemistry of Solid Wood, R. Rowell, Ed., American Chemical Society (ACS), Washington, DC, USA, 1984.

[4] T. Ozdemir, S. Hiziroglu, and A. Malkocoglu, "Influence of relative humidity on surface quality and adhesion strength of coated medium density fiberboard (MDF) panels," Materials and Design, vol. 30, no. 7, pp. 2543-2546, 2009.

[5] T. Ozdemir and S. Hiziroglu, "Influence of surface roughness and species on bond strength between the wood and the finish," Forest Products Journal, vol. 59, no. 6, pp. 90-94, 2009.

[6] E. Cheng and X. Sun, "Effects of wood-surface roughness, adhesive viscosity and processing pressure on adhesion strength of protein adhesive," Journal of Adhesion Science and Technology, vol. 20, no. 9, pp. 997-1017, 2006.

[7] A. V. Pocius, Adhesion and Adhesives Tech.: An Introduction, vol. 21, Hanser and Gardnes Publications, 2nd edition, 2002.

[8] J. Schultz and M. Nardin, "Theories and mechanism of adhesion," in Handbook of Adhesive Technology, pp. 19-35, Marcel Dekker, New York, NY, USA, 1994.

[9] E. Burdurlu, Y. Kiliç, G. C. Elibol, and M. Kiliç, "The shear strength of Calabrian pine (Pinus brutia ten.) bonded with polyurethane and polyvinyl acetate adhesives," Journal of Applied Polymer Science, vol. 99, no. 6, pp. 3050-3061, 2006.

[10] S. Hiziroglu, "Surface roughness analysis of wood composites: a stylus method," Forest Products Journal, vol. 46, no. 7-8, pp. 67-72, 1996.

[11] L. Mummery, Surface Texture Analysis. The Handbook, Hommelwelke, Muhlhausen, Germany, 1991.

[12] Z. W. Wick, F. N. Jones, and S. P. Papas, Organic Coatings: Science and Technology, Wiley Interscience, New York, NY, USA, 2nd edition, 1998.

[13] J. Vitosyto, K. Ukvalbergieno, and G. Keturakis, "The effects of surface roughness on adhesion strength of coated ash (Fraxinus excelsior L.) and Birch (Betula L.) wood," Medziagotyra, vol. 18, no. 4, pp. 347-351, 2012. 

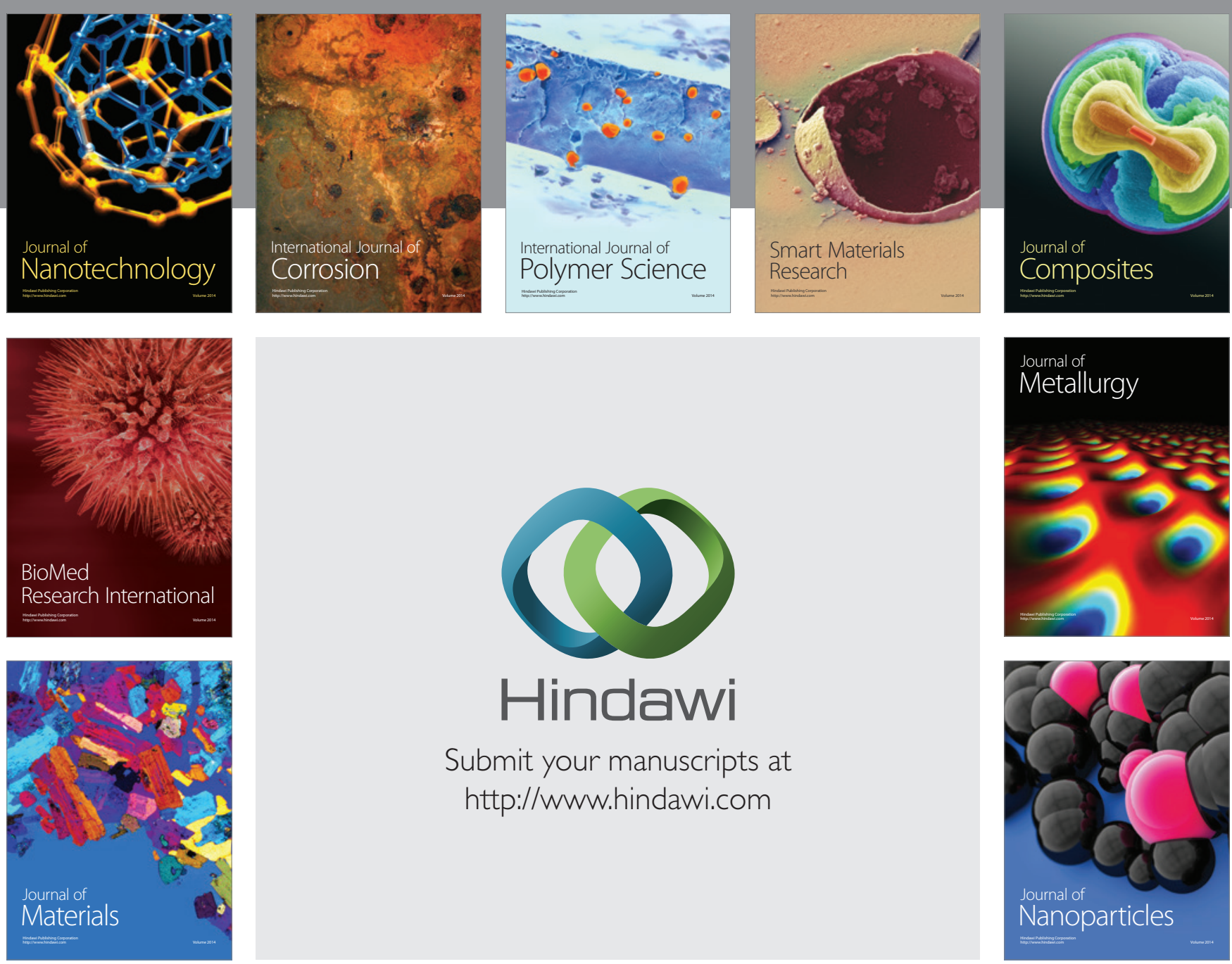

Submit your manuscripts at http://www.hindawi.com
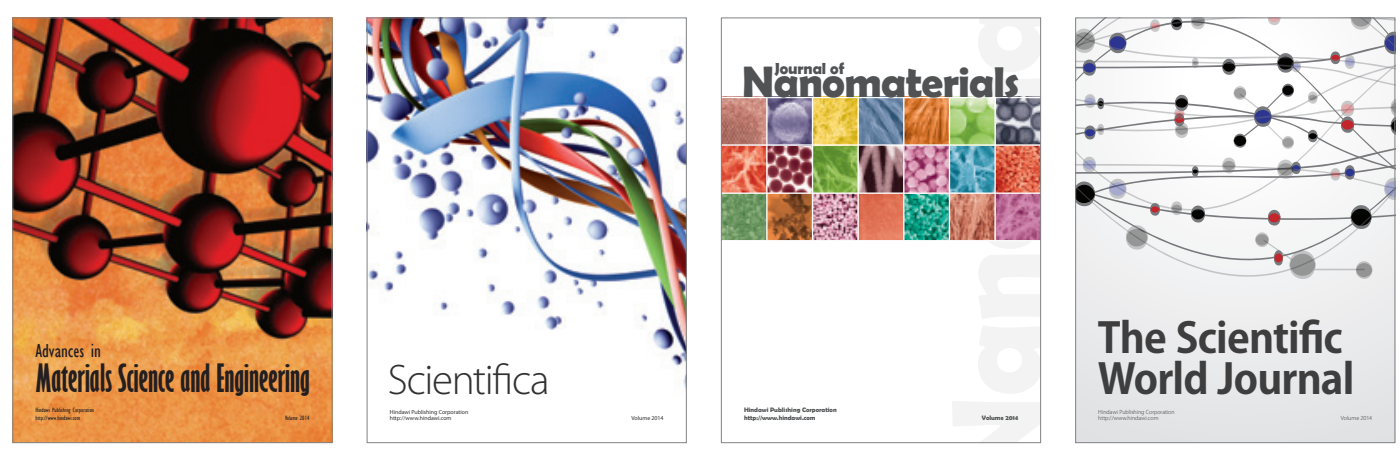

\section{The Scientific World Journal}
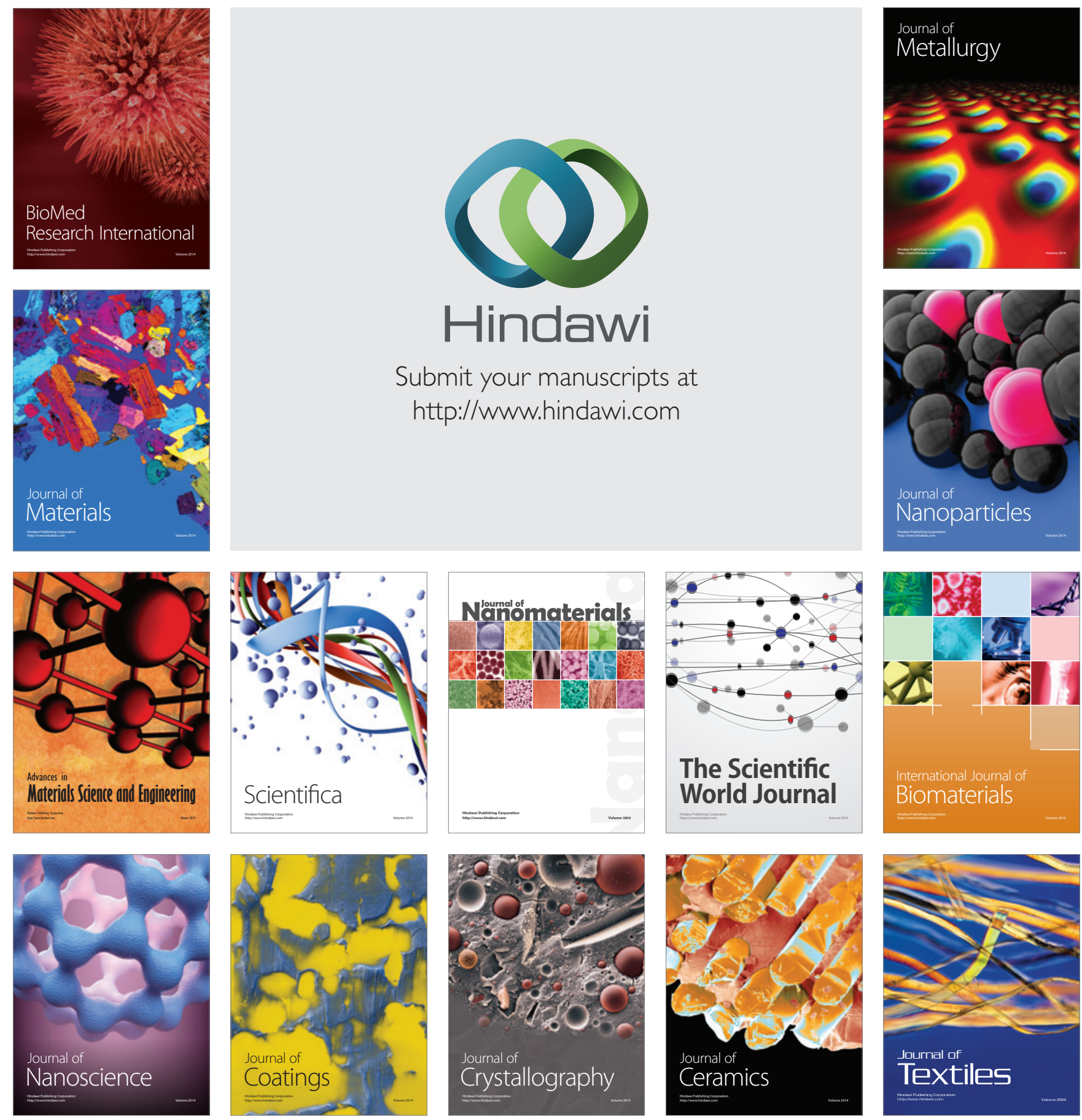